\title{
22. FLUCTUATIONS IN THE PAST RATES OF CARBONATE SOLUTION IN SITE 149: A COMPARISON WITH OTHER OCEAN BASINS AND AN INTERPRETATION OF THEIR SIGNIFICANCE
}

\author{
Anthony T. S. Ramsay, Department of Geology, University College of Swansea, \\ Swansea, South Wales, Great Britain \\ Nahum Schneidermann, Department of Marine Sciences, University of Puerto Rico, Mayaguez, Puerto Rico \\ and \\ J. W. Finch, Department of Geology, University College of Swansea, \\ Swansea, South Wales, Great Britain
}

\section{INTRODUCTION}

The abundance and diversity of calcareous plankton species in suspension in the modern ocean are determined by the influence of global temperatures on species diversity and the combined effect of atmospheric and hydrospheric circulation on organic productivity in the photic zone. The species composition and dominance of individual species within deep-sea sedimentary assemblages are, however, primarily a function of the resistance of calcareous tests to solution in the calcium carbonate undersaturated ocean deep-water. Resistance to solution is determined by the composition of the skeletal elements, i.e., calcitic or aragonitic, a low concentration of pores, the tendency to develop thickened tests with age in some species of planktonic foraminifera (Berger and Parker, 1970; Berger, 1971), and the presence or absence of a protective organic sheath in both the planktonic foraminifera and the calcareous nannoplankton (Berger, 1970; McIntyre and McIntyre, 1971).

The influence of species selective dissolution and the resulting modification of recent sedimentary assemblages of planktonic foraminifera is already documented for parts of the ocean (Berger, 1970, 1971). Modern calcareous nannoplankton assemblages which are similarly modified are recognized by McIntyre and McIntyre (1971) in sediments from the Atlantic and Indian oceans and their results have been substantiated and extended by Schneidermann (1972).

The affects of species selective dissolution are also evident in fossil foraminiferal and calcareous nannoplankton assemblages in deep-sea sediments. Depending on the degree of solution foraminiferal-nannofossil assemblages subjected to dissolution are characterized by a decreasing ratio of planktonic to benthonic foraminiferal tests, the fragmentation of planktonic foraminiferal tests, low species diversity, and/or species with more massive tests (Cita 1971). Ultimately planktonic foraminiferal tests becorne rare or are totally absent. The dissolution of planktonic foraminiferal tests is accompanied by the enrichment of the sediment in the more resistant calcareous nannofossils and leads to the formation of nannoplankton chalk or ooze.

Species selective dissolution in Eocene nannofossil assemblages is indicated by an increase in the percentage of some species of Discoaster (Ramsay, 1972a). The data presented in this report show that Miocene and Pliocene nannofossil assemblages are similarly affected.

Solution-induced species patterns in ancient deep-sea sequences provide information on past rates of calcium carbonate solution in the oceans. Although most interpretations are based on analyses of planktonic foraminiferal assemblages, calcareous nannofossils are potentially equally useful and possibly even superior indicators of solution at depth. Apart from their abundance, they are also more resistant to solution than planktonic foraminiferal tests and therefore provide information on sediments in which these organisms are either rare or absent as a result of solution.

\section{DISCUSSION OF SITE 149 AND COMPARISON WITH OTHER DSDP SITES}

Site 149 which is situated in the center of the Venezuelan Basin provides an ideal section for investigating past rates of carbonate dissolution. Although the core has been disturbed in parts by drilling, it nevertheless contains an essentially complete record of pelagic sedimentation from the Paleocene to the Recent. The core descriptions also indicate that Site 149 contains an alternating sequence of pelagic sediments which were influenced by varying degrees of dissolution. Similar sequences in the Atlantic and Pacific are interpreted by Hay (1971) and Ramsay (1972b) in terms of fluctuations in the calcite compensation depth, and in the rate of calcite solution.

Our interpretation of Site 149 is based on a comparison between vertical changes in the abundance of solutionresistant species of Discoaster (see Table 1) in the nannofossil fraction and variations in the calcium carbonate content of the sediment. Although the samples which were investigated for their carbonate content do not always coincide with the sample which we examined, a comparison of these analyses shows a distinct parallelism in the trends of both parameters. The data presented in Figure 1 show a negative correlation $(R=-0.725$ at 53 df with a significance level of 0.001 ) between changes in the percentage of Discoaster in the nannofossil assemblage and changes in the carbonate content of the sediment. This comparison indicates that the dissolution of calcium carbonate was accompanied by a simultaneous increase in both the noncarbonate fraction of the sediment and the solution-resistant elements of the nannofossil assemblage. In Late Miocene and Pliocene samples the elements most resistant to solution are 
TABLE 1

Variations in the Abundance of

Discoaster in the Nannofossil

Fraction of the Sediments of Site 194

\begin{tabular}{|c|c|c|c|}
\hline Core & Section & $\begin{array}{c}\text { Top of } \\
\text { Interval } \\
(\mathrm{cm})\end{array}$ & $\%$ Discoaster \\
\hline 9 & 5 & 77 & 8 \\
\hline 9 & 5 & 85 & 65 \\
\hline 9 & 5 & 93 & 59 \\
\hline 9 & 6 & 4 & 24 \\
\hline 9 & 6 & 22 & 0 \\
\hline 9 & 6 & 92 & 98 \\
\hline 10 & 4 & 75 & 18 \\
\hline 10 & 4 & 80 & 0 \\
\hline 11 & 1 & 133 & 80 \\
\hline 11 & 2 & 20 & 0 \\
\hline 11 & 2 & 55 & 77 \\
\hline 11 & 3 & 121 & 0 \\
\hline 11 & 4 & 52 & 0 \\
\hline 11 & 4 & 56 & 0 \\
\hline 11 & 6 & 141 & 0 \\
\hline 12 & 3 & 76 & 91 \\
\hline 12 & 3 & 96 & 43 \\
\hline 12 & 4 & 100 & 35 \\
\hline 12 & 6 & 128 & 40 \\
\hline 13 & 2 & 55 & 46 \\
\hline 13 & 3 & 37 & 22 \\
\hline 13 & 3 & 110 & 45 \\
\hline 13 & 6 & 52 & 62 \\
\hline 13 & 6 & 55 & 0 \\
\hline 14 & 3 & 94 & 48 \\
\hline 14 & 4 & 118 & 0 \\
\hline 14 & 4 & 144 & 0 \\
\hline 15 & 1 & 15 & 0 \\
\hline 15 & 1 & 97 & 0 \\
\hline 15 & 2 & 98 & 58 \\
\hline 15 & 2 & 105 & 35 \\
\hline 15 & 3 & 25 & 20 \\
\hline 15 & 3 & 39 & 34 \\
\hline 15 & 3 & 82 & 16 \\
\hline 15 & 3 & 99 & 50 \\
\hline 15 & 4 & 22 & 29 \\
\hline 15 & 4 & 101 & 18 \\
\hline 15 & 4 & 107 & 22 \\
\hline 15 & 5 & 12 & 21 \\
\hline 15 & 5 & 36 & 19 \\
\hline 16 & 1 & 74 & 40 \\
\hline 16 & 2 & 40 & 38 \\
\hline 16 & 2 & 105 & 33 \\
\hline 16 & 3 & 25 & 29 \\
\hline 16 & 3 & 99 & 25 \\
\hline 16 & 4 & 82 & 60 \\
\hline 16 & 4 & 129 & 46 \\
\hline 16 & 5 & 25 & 47 \\
\hline 16 & 5 & 110 & 26 \\
\hline 17 & 2 & 119 & 26 \\
\hline 17 & 4 & 106 & 41 \\
\hline 17 & 5 & 58 & 25 \\
\hline 23 & 5 & 25 & 12 \\
\hline 23 & 5 & 100 & 8 \\
\hline 24 & 1 & 98 & 14 \\
\hline 25 & 3 & 99 & 9 \\
\hline
\end{tabular}

TABLE 1 - Continued

\begin{tabular}{|c|c|c|c|}
\hline Core & Section & $\begin{array}{l}\text { Top of } \\
\text { Interval } \\
\text { (cm) }\end{array}$ & \% Discoaster \\
\hline 26 & 1 & 98 & 19 \\
\hline $\begin{array}{l}27 \\
27\end{array}$ & $\begin{array}{l}3 \\
3\end{array}$ & $\begin{array}{l}25 \\
99\end{array}$ & $\begin{array}{l}17 \\
15\end{array}$ \\
\hline 28 & 2 & 25 & 11 \\
\hline 29 & 2 & 25 & 17 \\
\hline 30 & 2 & 25 & 1 \\
\hline $\begin{array}{l}31 \\
31\end{array}$ & $\begin{array}{l}1 \\
2\end{array}$ & $\begin{array}{l}47 \\
19\end{array}$ & $\begin{array}{l}87 \\
90\end{array}$ \\
\hline $\begin{array}{l}32 \\
32 \\
32 \\
32\end{array}$ & $\begin{array}{l}1 \\
3 \\
4 \\
4\end{array}$ & $\begin{array}{r}131 \\
119 \\
84 \\
145\end{array}$ & $\begin{array}{r}89 \\
69 \\
45 \\
0\end{array}$ \\
\hline $\begin{array}{l}33 \\
33\end{array}$ & $\begin{array}{l}1 \\
2\end{array}$ & $\begin{array}{l}131 \\
113\end{array}$ & $\begin{array}{r}0 \\
55\end{array}$ \\
\hline $\begin{array}{l}34 \\
34\end{array}$ & $\begin{array}{l}1 \\
3\end{array}$ & $\begin{array}{r}99 \\
120\end{array}$ & $\begin{array}{l}45 \\
44\end{array}$ \\
\hline $\begin{array}{l}35 \\
35 \\
35 \\
35 \\
35 \\
35 \\
35\end{array}$ & $\begin{array}{l}1 \\
2 \\
2 \\
3 \\
4 \\
5 \\
6\end{array}$ & $\begin{array}{r}96 \\
49 \\
87 \\
7 \\
76 \\
118 \\
136\end{array}$ & $\begin{array}{r}31 \\
40 \\
4 \\
37 \\
52 \\
34 \\
19\end{array}$ \\
\hline 36 & 1 & 119 & 0 \\
\hline $\begin{array}{l}37 \\
37 \\
37\end{array}$ & $\begin{array}{l}1 \\
3 \\
4\end{array}$ & $\begin{array}{r}110 \\
14 \\
57\end{array}$ & $\begin{array}{l}14 \\
20 \\
35\end{array}$ \\
\hline $\begin{array}{l}38 \\
38\end{array}$ & $\begin{array}{l}2 \\
2\end{array}$ & $\begin{array}{l}38 \\
76\end{array}$ & $\begin{array}{r}25 \\
0\end{array}$ \\
\hline $\begin{array}{l}41 \\
41 \\
41 \\
41 \\
41 \\
41\end{array}$ & $\begin{array}{l}1 \\
2 \\
2 \\
4 \\
4 \\
6\end{array}$ & $\begin{array}{r}59 \\
110 \\
146 \\
69 \\
121 \\
148\end{array}$ & $\begin{array}{l}51 \\
66 \\
32 \\
53 \\
28 \\
20\end{array}$ \\
\hline $\begin{array}{l}42 \\
42 \\
42\end{array}$ & $\begin{array}{l}3 \\
3 \\
4\end{array}$ & $\begin{array}{r}75 \\
148 \\
143\end{array}$ & $\begin{array}{l}48 \\
26 \\
42\end{array}$ \\
\hline
\end{tabular}

members of the species Discoaster brouweri which in one sample (149-9-6, 92-93) makes up 93\% of the nannofossil assemblage. In Late Eocene sediments, elements of the species Discoaster barbadiensis and D. saipanensis show maximum resistance to solution, and in Sample $15-149-3102(19-20 \mathrm{~cm})$ constitute $64 \%$ and $25 \%$ of the nannofossils respectively. Forms assigned to Discoaster barbadiensis dominate Middle Eocene nannofossil assemblages which were affected by dissolution.

The vertical changes in the calcium carbonate and Discoaster content of Site 149 sediments are illustrated in Figure 2. The close correspondence between the oscillations which occur in both parameters is in our opinion not fortuitous. Although all the sediments which we examined show some evidence of dissolution, nannoplankton assem- 


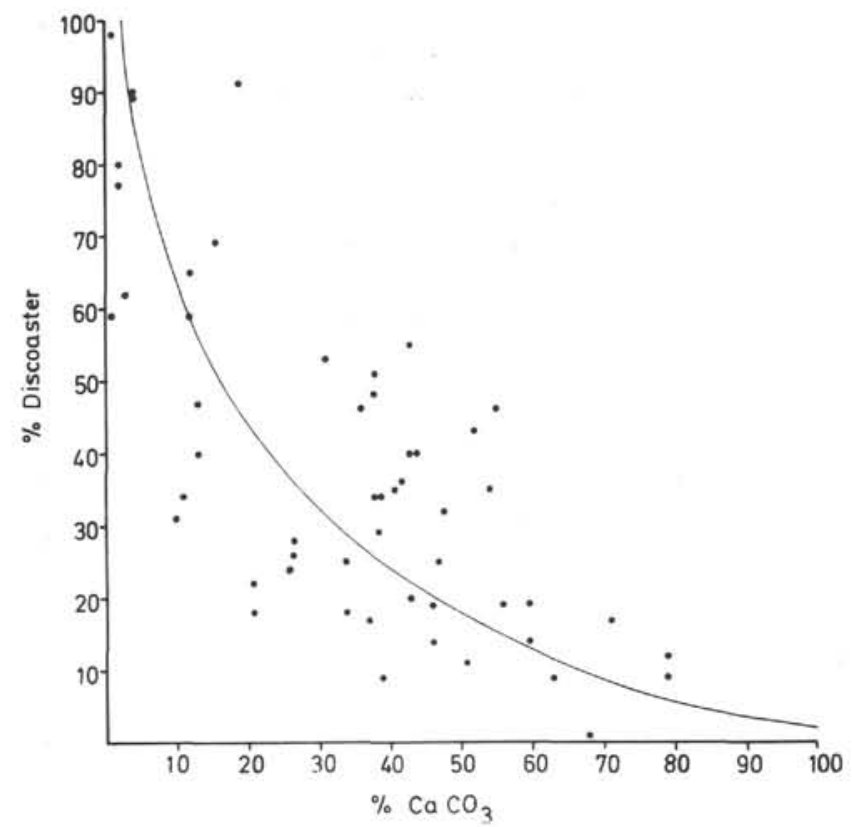

Figure 1. The relationship between Discoaster and calcium carbonate in the sediments of Site 149. The vertical scale represents the percentage of Discoaster in the nannofossil fraction.

blages which contain a high percentage of Discoaster and a low carbonate content, or sediments which contain no carbonate, very possibly reflect deposition during intervals which were characterized by elevated rates of carbonate dissolution. In Site 149 (see Figure 2) there is evidence for nine intervals of increased solution; three Paleogene intervals in which biogenic siliceous sediments predominate, and six intervals in the Middle Miocene to Late Pliocene sequence which are represented by marls or clays. The carbonate and Discoaster analyses for the Oligocene sediments indicate a reduced rate of dissolution for the duration of this epoch.

The alternation of sediments characterized by varying degrees of carbonate dissolution in Site 149 could be produced by one of three mechanisms:

1) By vertical movements of the sea floor through a water column in which the rate of carbonate dissolution and consequently the calcite compensation depth have remained in a steady state.

2) The redeposition of carbonates deposited on the flanks of the Venezuelan Basin onto the floor of a basin which was situated below the calcite compensation depth.

3) Changes in the surface productivity of calcareous organisms, and associated temporal fluctuations in the calcite compensation depth and other solution levels.

We have rejected vertical tectonics and redeposition as possible mechanisms for producing the alternation of different dissolution facies recorded at Site 149 for the following reasons: a) this phenomenon is widely distributed in the pelagic sequences of other ocean basins (see Figure 2, and Ramsay, 1972b); b) parts of the alternating sequence of different dissolution facies in Site 149 are synchronous with similar sequences recovered from less complete sections at other DSDP sites (see Figure 3); c) because there is no geophysical or structural evidence for vertical tectonics, or sedimentological evidence for redeposition at Site 149.

We consider that the vertical changes in the carbonate and Discoaster content of Site 149 sediments and the alternation of different dissolution facies in Tertiary midlatitude sequences at other DSDP sites are best explained in terms of temporal fluctuations in the calcite compensation depth and other solution levels, and that these fluctuations were associated with changes in the surface productivity of calcareous organisms through the Tertiary. Variations in the surface productivity of the calcareous plankton were probably related to changes in global temperature. This view is based on the similarity between the oxygen $\left(\delta \mathrm{O}^{18}\right)$ isotope palaeotemperature curve from the Paleocene to the Quaternary, compiled from data published by Devereaux (1967) and Douglas and Savin (1971), and the proposed curve for fluctuations in the calcite compensation depth for the same time interval (see Figure 3), compiled by Ramsay (1972b); and the somewhat cruder correlation between these curves and the Tertiary record of phytoplankton productivity and abundance compiled by Tappan (1968). During warm periods enhanced phytoplankton production corresponds with an elevated calcite compensation depth. In cooler periods both phytoplankton productivity and the calcite compensation depth are depressed.

If our interpretation of sequences which are characterized by alternations of different dissolution facies is correct, then Site 149 contains the most complete record of temporal fluctuations in the calcite compensation depth, and of surface plankton production recovered by DSDP for the Tertiary of the Atlantic/Caribbean area. A comparison of Site 149 with other DSDP sites (see Figure 3) demonstrates both the correspondence in sedimentary events which was caused by simultaneous fluctuations in the calcite compensation depths of different ocean basins (e.g., the Pliocene deposits of Sites $149,29,6 / 7,9,10,13$, and 2 ) and the variation in the history of sedimentation of these sites. This variation is due to the various depths of deposition at each site through the Tertiary and to the position of the calcite compensation depth in the water column, which, whether elevated or depressed, probably differed within and for each ocean basin. The sedimentary history of the Atlantic sites is also complicated by the fact that these deposits accumulated on the descending flanks of the spreading mid-Atlantic Ridge. Whereas some sites (e.g., Sites 6,7 , and 9) were situated below the calcite compensation depth through much of the Tertiary, others such as Site 20 were probably carried within the range of the fluctuating compensation depth on the descending oceanic crust.

\section{AN INTERPRETATION OF FLUCTUATIONS IN THE CALCITE COMPENSATION DEPTH}

In modern oceans, away from the continental margins, the position of the calcite compensation depth in the water column is very much a product of the rate of supply of calcium carbonate to the ocean bottom and its rate of solution at depth (Lisitzin, 1971). The record of a fluctuating calcite compensation depth in Atlantic, Caribbean, and Pacific (Ramsay, 1972b) Tertiary mid-latitude sections suggest that these parameters have also varied. 


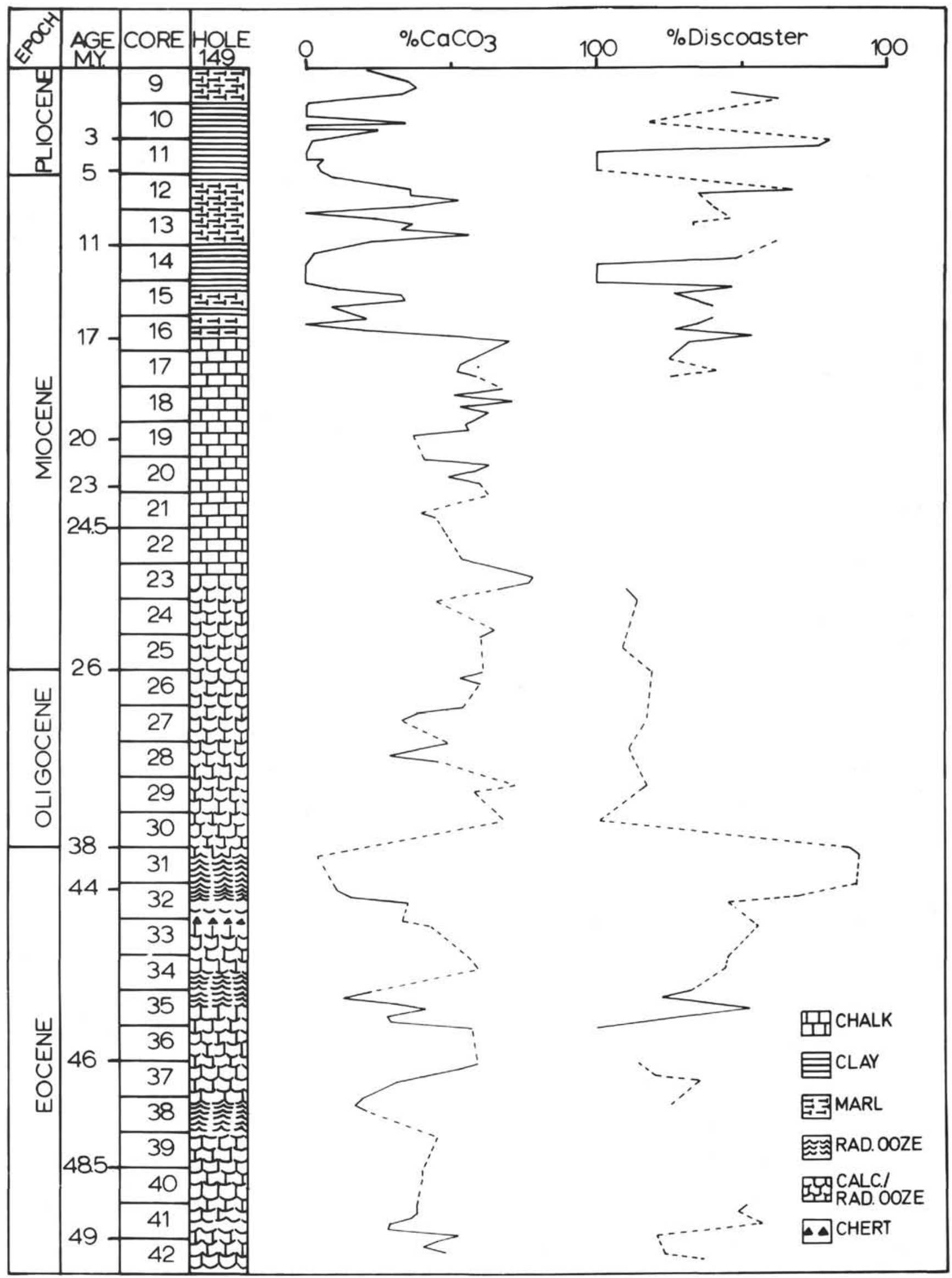

Figure 2. A comparison between the nature of Site 149 sediments and their Discoaster content. Time scale after Berggren in Maxwell et al. (1970). 


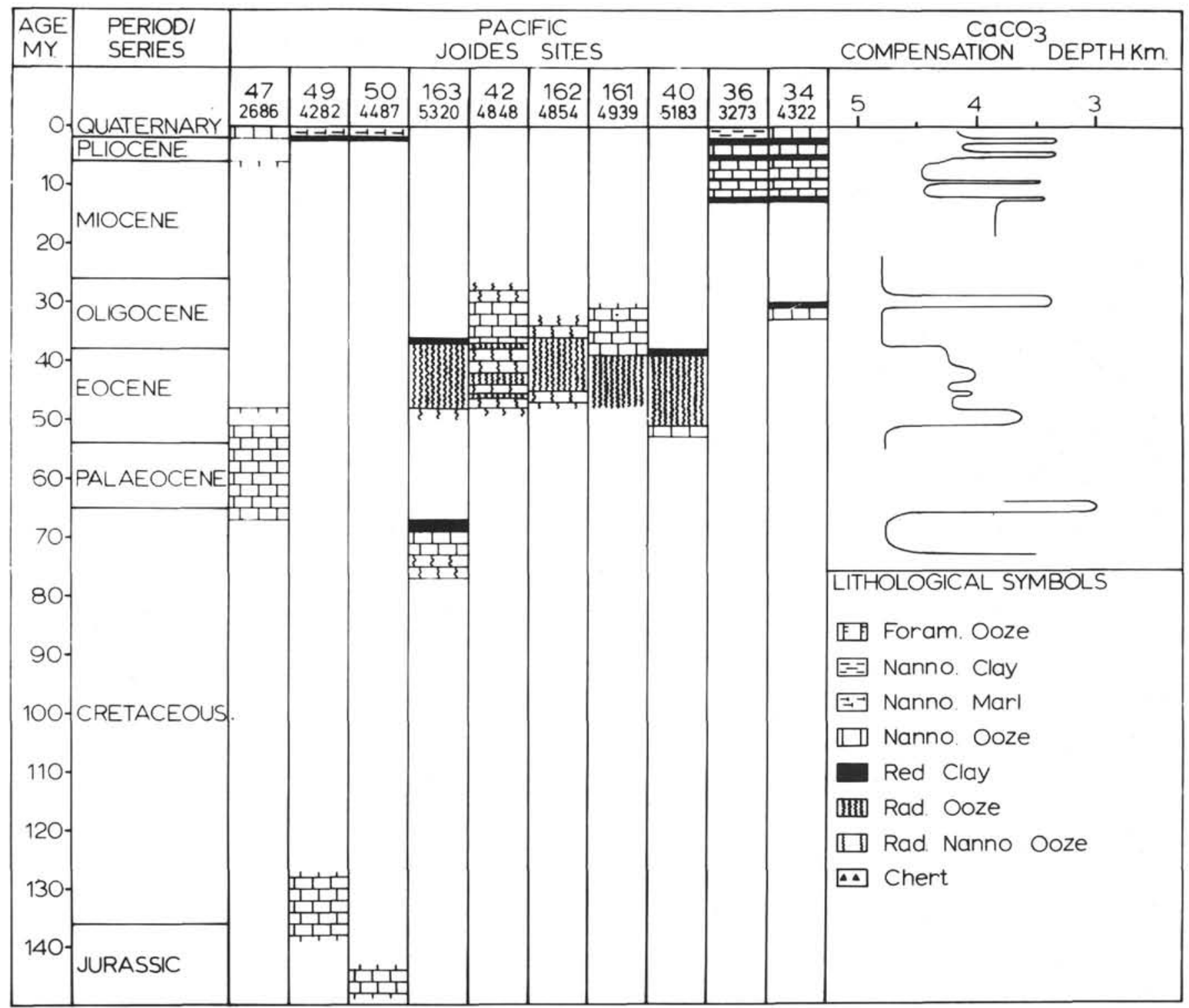

Figure 3. Schematic representation of the vertical fluctuations in the calcite compensation depth for the Pacific plotted against time. Time scale after Berggren in Maxwell et al. (1970) and Harland et al. (1964).

Thus the depressed nature of the calcite compensation depth during cool intervals may have resulted from an increase in the rate of supply of calcium carbonate to the ocean floor together with a decrease in its rate of solution at depth. In the absence of adequate data for Tertiary high latitude sequences it is not possible to resolve whether this situation could have applied to the whole Tertiary ocean or only to its mid-latitudes.

A comparison between the Tertiary and Quaternary records of carbonate sedimentation in mid-latitudes indicates that they are analogous in that they both bear the imprint of climatic variations.

The Quaternary mid-latitude sequences are characterized by carbonate cycles (Arrhenius, 1952; Hays et al., 1969; Olausson, 1971) which indicate maximum carbonate deposition during glacial periods and reduced carbonate sedimentation during interglacial episodes. In the Pacific and Indian ocenas, the alternations of glacial carbonate or siliceous carbonate ooze with interglacial siliceous ooze in cores obtained close to the modern calcite compensation depth suggest that the compensation depth was elevated during warm intervals and depressed during cold episodes. The increase in numbers of solution-resistant species of planktonic foraminifera and coccoliths contained in carbonates deposited above the calcite compensation depth during interglacial cycles (Olausson, 1971; Zobel in Berger, 1971; Schneidermann, 1971) suggest that the solution rate of calcite at depth was also elevated during interglacial episodes.

The history of carbonate sedimentation in the high latitudes of the Quaternary North Atlantic basin is the complete reverse of the equatorial and mid-latitude record. Here the glacial episodes are represented by carbonate minima and the interglacial intervals by carbonate maxima (Olausson, 1971; McIntyre et al., 1972). Although Olausson (1971) attributes this record to enhanced solution during 


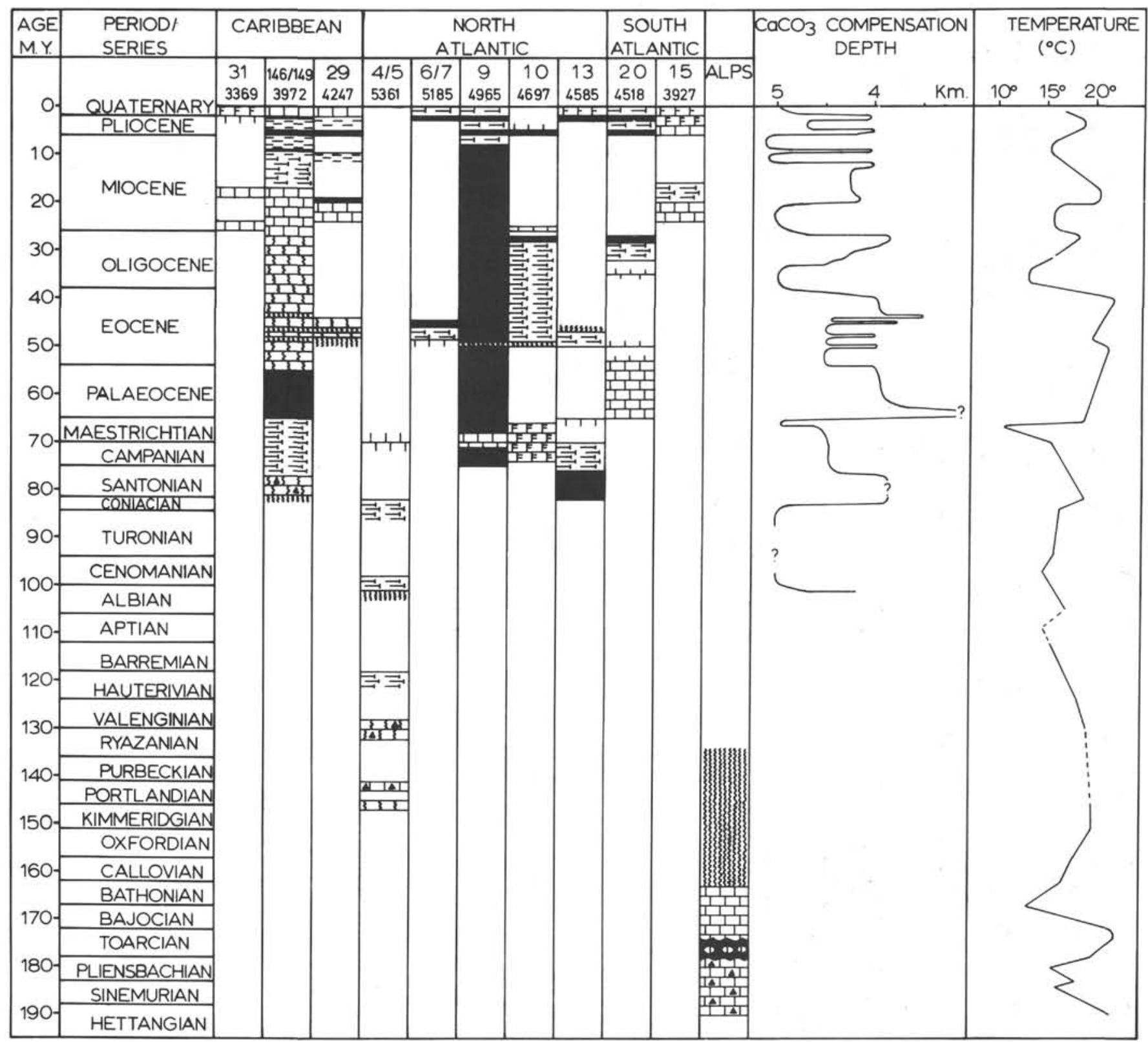

Figure 4. Schematic representation of vertical fluctuations in the calcite compensation depth for the Atlantic and Caribbean, plotted against time and compared with a graph of Jurassic-Recent temperatures. Time scale after Berggren in Maxwell et al. (1970) and Harland et al. (1964).

glacial cycles, the data presented by McIntyre et al. (1972) indicate that the carbonate minima accompany periods of reduced carbonate production which were associated with the southward penetration of cold polar water during glacial intervals.

If the North Atlantic record is typical of high-latitude sequences in other ocean basins, then it is possible that the fluctuations of the calcite compensation depth in midlatitudes during the Quaternary was controlled by the productivity of carbonate organisms in high latitudes. During warm episodes the increased production and sedimentation of calcareous organisms in high latitudes was accompanied and compensated for by the elevation of the calcite compensation depth in low and mid-latitudes.
During glacial intervals the reduced surface production and sedimentation of calcareous organisms in high latitudes is reflected by a depressed calcite compensation depth, and possibly a decreased rate of carbonate solution at depth, in mid- and low latitudes.

The hypothesis outlined above is attractive in that it accounts for the synchronism in the fluctuations of the calcite compensation depth in mid-latitude sequences of different ocean basins during the Quaternary. It is possible that the Tertiary fluctuations in the calcite compensation depth were also controlled by the influence of climatic variation on the surface production of the calcareous plankton in high latitudes. Drilling by DSDP in these latitudes should provide the necessary information to test 
this hypothesis. On the basis of this theory one would expect that in Tertiary high latitude sequences, which were deposited above the calcite compensation depth, cool intervals like the Oligocene and Lower Miocene will be characterized by carbonate minima, while the warmer Paleocene and Middle Miocene intervals will be characterized by carbonate maxima.

\section{REFERENCES}

Arrhenius, G. O. S., 1952. Sediment cores from the east Pacific. Repts. Swedish Deep-Sea Exped. 5, (1). 227 p.

Berger, W. H., 1970. Planktonic foraminifera: selective solution and the lysocline. Marine Geol. 8, 111. , 1971. Sedimentation of planktonic foraminifera. Marine Geol. 11, 325.

Berger, W. H. and Parker, F. L., 1970. Diversity of planktonic foraminifera in deep-sea sediments. Science. $168,1345$.

Cita, M. B., 1971. Palaeoenvironmental aspects of DSDP Legs I-IV. Proc. 2nd. Planktonic Conf., Roma. 251.

Devereux, I., 1967. Oxygen isotope measurements of New Zealand Tertiary fossils. New Zealand J. Sci. 10, 988.

Douglas, R. G. and Savin, S. M., 1971. Isotopic analysis of planktonic foraminifera from the Cenozoic of the northwest Pacific, Leg 6. In Fischer, A. G. et al., 1971. Initial Reports of the Deep Sea Drilling Project, Volume VI. Washington (U.S. Government Printing Office). 1123.

Harland, W. B., Smith, A. G. and Wilcock, B. (Eds.), 1964. The Phanerzoic time-scale. Quart. J. Geol. Soc. London. $1205,260$.

Hay, W. W., 1971. Leg 4 of the Deep Sea Drilling Project. Science. 172, 1197.

Hays, J. D., Saito, T., Opdyke, N. D. and Burckle, L. H., 1969. Pliocene-Pleistocene sediments of the Equatorial
Pacific: Their palaeomagnetic, biostratigraphic, and climatic record. Bull. Geol. Soc. Am. 80, 1481.

Lisitzin, A. P., 1971. Distribution of carbonate microfossils in suspension and in bottom sediments. In Funnell, B. M. and Riedel, W. R. (Eds.) The Micropalaeontology of Oceans. Cambridge (Cambridge University Press). 197.

Maxwell, A. E., et al., 1970. Initial Reports of the Deep Sea Drilling Project, Volume III. Washington (U. S. Government Printing Office). $806 \mathrm{p}$.

McIntyre, A. and McIntyre, R., 1971. Coccolith concentrations and differential solution in oceanic sediments. In Funnell, B. M. and Riedel, W. R. (Eds.), The Micropalaeontology of Oceans. Cambridge (Cambridge Univ. Press). 253.

McIntyre, A., Ruddiman, W. F. and Jantzen, R., 1972. Southward penetrations of the North Atlantic Polar Front: faunal and floral evidence of large-scale surface water mass movements over the last 225,000 years. Deep Sea Res. 19, 61 .

Olausson, E., 1971. Quaternary correlations and the geochemistry of oozes. In Funnell, B. M. and Riedel, W. R. (Eds.), The Micropalaeontology of Oceans. Cambridge (Cambridge Univ. Press). 375.

Ramsay, A. T. S., 1972a. Aspects of the distribution of fossil species of calcareous nannoplankton in North Atlantic and Caribbean sediments. Nature. 236, 67.

, 1972b. The distribution of calcium carbonate in deep-sea sediments. In Geologic History of Oceans, Hay, W. W. (Ed.). Soc. Econ. Paleontol. Mineral. Spec. Publ.

Schneidermann, N., 1972. Selective dissolution of Recent Coccoliths in the Atlantic Ocean. Unpublished Ph.D. Thesis.

Tappan, H., 1968. Primary production, isotopes, extinctions and the atmosphere. Paleogeog., Paleoclim., Paleoecol. 4, 187. 